\title{
HEALTH CADRE ADVOCACY FOR EARLY DETECTION OF PSYCHOLOGICAL DISORDER IN THE ELDERLY
}

\author{
Rahmah Saniatuzzulfa' ${ }^{1}$, Rini Setyowati'1), \\ Rohmaningtyas Hidayah Setyaningrum²) \\ 1)Department of Psychology, Faculty of Medicine, Universitas Sebelas Maret \\ 2)Department of Psychiatry, Faculty of Medicine, Universitas Sebelas Maret
}

\begin{abstract}
Background: The higher prevalence of psychological disorders in the elderly is caused by the lack of knowledge on how to early detect problems experienced by elderly. The purpose of the community service is to provide cadres with psychoeducation in early detection of psychological disorders in the elderly. This study aimed to examine the effect of health cadre advocacy for early detection of psychological disorder in the elderly.

Subjects and Method: This was a quasi-experiment study with one group pre-test and posttest design conducted in Kartasura, Sukoharjo, Central Java. The advocacy approach used in this study was community education through contextual teaching and learning. A total of 22 study subjects was included in this study, consisting of family welfare development management, the elderly health post cadres, hamlet head, and neighbors. The independent variable was health cadre advocacy. The dependent variables were knowledge and skill in early detection of psychological disorder. The data were collected by questionnaire and analyzed using Wilcoxon test.

Results: Scores in knowledge and skill in early detection of psychological disorder were higher after health cadre advocacy than before, and it was statistically significant.

Conclusion: Health cadre advocacy is effective to improve knowledge and skill of health cadres in early detection of psychological disorders in the elderly.
\end{abstract}

Keywords: health cadres, advocacy, elderly, psychological disorder

\section{Correspondence:}

Rahmah Saniatuzzulfa, Rini Setyowati, Rohmaningtyas Hidayah Setyaningrum. Universitas Sebelas Maret, Jl. Ir. Sutami 36 A Kentingan Surakarta, Central Java.

Email: rsaniatuzzulfa@gmail.com, rini.setyowati87@gmail.com, astitdr@gmail.com.

Mobile: 08985116163, 085727755750, 081226361555 .

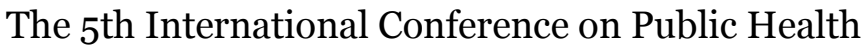

Best Western Premier Hotel, Solo, Indonesia, February 13-14, $2019 \mid 160$

https://doi.org/10.26911/theicph.2019.02.05 